\title{
Who speaks for whom? A look at civil society accountability in bioprospecting debates in Mexico. Alexandra Hughes ${ }^{1}$
}

\section{Introduction}

Recent trends in governance include a diminishing role of the nation state and an expanding role of non-government actors in the management of resources and services. The nation state, some argue, is ceding way to a plethora of institutions including global, multinational, regional, and local-level players. Within this multilevel, multi-institutional governance system the role of both the private sector and civil society in governance and development is attracting much attention, particularly with respect to accountability issues. As a result, a 'complex and dense set of obligations and responsibilities between different actors in the field of development' are emerging, 'result[ing] both in new mechanisms ensuring accountable behaviour and [in] new "accountability gaps"' (Bellour and Newell 2001.)

Civil society (CS) is often seen as a 'watchdog' of government and private actors, participating in public forums, campaigning and advocating for greater accountability and respect for citizens' rights. Out of these 'civil regulation' processes, however, civil society organisations and multinational corporations have sometimes emerged as 'unlikely bedfellows' (ibid: 2). Global alliances are blurring national and institutional boundaries, establishing relationships and initiatives without clearly defined constituencies. The heterogeneous multi-level nature of CS, and the complex and dynamic context within which it operates, raise questions for research and debate around its own accountability. This is of particular relevance in terms of struggles for environmental rights, where property rights of 'global' environmental resources are hazily defined.

This article examines a case that illustrates the challenges associated with civil society accountability (CSA) in the context of a struggle for rights associated with biodiversity conservation and development. It looks at civil society's role in Mexico's debate around 'the exploration, extraction and screening of biological diversity and indigenous knowledge for commercially valuable genetic and biochemical resources' (Pimbert 1997: 422), or bioprospecting. In so doing, it explores a number of questions that are raised regarding the way CS representation, responsibility, and voice are played out in a legislative vacuum where rights to access and benefits from biodiversity - be they cultural, economic, environmental or knowledge-based remain ambiguous and contested. How have CS actors presented indigenous people's cultural, economic, environmental and knowledge rights in the bioprospecting debate? How do these presentations vary? What do these contrasts and differences tell us about issues of representation and legitimacy in developing and maintaining civil society's own accountability?

With the aim of addressing these issues, this article is structured as follows. Section 1 presents the ambiguities found in the legislation that guides bioprospecting in Mexico. Its second part introduces the two bioprospecting initiatives around which Mexico's bioprospecting debate is centred, and the way public claim processes carried out by CS actors make use of existing legislation and loop holes to articulate on behalf of local and indigenous peoples' rights. This sets the stage for an exploration of our main case study, that of the UZACHI-Sandoz bioprospecting project. Section 2 describes this particular initiative, introducing its key actors and situating them historically in a broader regional struggle for natural resources in the area. In section 3, problems and questions raised by these contradicting positions in 
terms of civil society accountability and related issues of cultural, economic environmental and knowledge rights are explored more fully.

\section{Section 1: Legislative mechanisms, gaps and debate in Mexico's bioprospecting arena}

Proponents of bioprospecting see it as a means through which biologically diverse countries and localities can profit from their natural endowment(s). Critics of bioprospecting make two broad arguments. Radical critics consider the commodification and privatisation of biological resources, and the knowledge base that underpins their utility, as a threat to both biological and cultural diversity. Their argument is that in practice bioprospecting does not value biodiversity until it is absorbed into international commodity circuits (McAfee 1999: 138-139), and that through shifting common resources into areas of capital concentration, they are alienating them from their original custodians (Shiva 1997: 72). This is seen to have negative repercussions for biodiversity's traditional users as it devalues local knowledge systems, displaces local rights, and creates a monopoly of rights to diversity (1997: 68).

Other more reformist critics see no problem inherent to bioprospecting, and are more concerned with the ambiguous legislation and policies that govern it in practice. Both levels of criticism are played out in Mexico's debate around bioprospecting.

The 1992 multilateral Convention on Biological Diversity (CBD) has attempted to reconcile the conservation of biodiversity with its development, making specific reference to 'the sustainable use of [biodiversity's] components and the fair and equitable benefits arising out of the utilization of genetic resources...' (Article 1). However, the ambiguity surrounding biodiversity-related property rights leads to contradictions in the document.

On the one hand, the CBD's Article 15 confirms the sovereign rights of states over their biological resources, demanding that access to these resources occur under the prior informed consent of, and on 'mutually agreed terms' with source-country governments. On the other, its Article 8(j) commits nation-states to 'respect, preserve and maintain knowledge, innovations and practices of indigenous and local communities embodying traditional lifestyles relevant for the conservation and sustainable use of biological diversity... and [to] encourage the equitable sharing of the benefits arising from the utilization of such knowledge, innovations and practices'. Differing interpretations of these Articles and their respective prevalence can lead to further complications and challenges associated with operationalising the Convention. This is particularly true for developing countries blessed with biologically diverse areas but also characterised by a history of unequal and detrimental relations between indigenous/ local communities inhabiting such areas, and state governments.

In Mexico the political void resulting from the absence of a clear legislative framework specifically regulating bioprospecting access and benefit sharing (ABS) arrangements adds to the obvious problems born of differentiated power relations between project stakeholders. Mexico ratified the CBD in 1993, and although 1996 revisions to Mexico's Law of Ecological Balance and Environmental Protection (LGEEPA) do not outline precise guidelines regulating bioprospecting, its Articles 87 and 87Bis. do address the collection of wild flora and fauna for "biotechnological" use. Reiterating the CBD's Article 8(j), this law 'mandat[es] that such collections proceed only with the permission of the legitimate landowners, and that benefits from the elaboration of these resources accrue to those landowners' (Hayden 2000: 121). 
Further marking a political shift towards shared governance in this arena is another 1996 revision, LGEEPA's Article 189. The LGEEPA denuncia, or public claims mechanism, stipulates that 'all persons, social groups, non-governmental organisations, associations and companies (sociedades) can present public claims regarding any event, act or neglect that produces or might produce ecological disequilibrium or environmental damage'. It is within this legislative framework that CS actors publicly denounced two on-going bioprospecting projects, instigating a heated public debate.

In February 2000, with the support of various other CS actors, the Organización de Médicos Indígenas del Estado de Chiapas, (Chiapas' Organisation of Indigenous Healers), or OMIECh, used this denuncia mechanism to legally challenge a bioprospecting initiative funded by the US government's International Cooperative Biodiversity Groups (ICBG). In its public claim, OMIECh contested that their demand for the legal protection of their knowledge and natural resources - a prerequisite to their participation in the project - was not fulfilled. They also expressed concern over the privatisation of collected materials - something they felt contradicted indigenous culture in the area. One month later, a coalition of CS organisations similarly denounced a bioprospecting agreement established between the Universidad Nacional Autónoma de México (UNAM) and the US-based company, Diversa. Through this agreement, the latter was given access to all micro-organisms collected in Mexico by the University's Biotechnology Institute. Among other things, the public claim asserted that the UNAM is not a government body nor the legitimate landholder in collection areas, and therefore not the legitimate owner of the micro-organic samples it had negotiated to exchange with Diversa. Both contracts were thus considered to undermine the CBD's Article 8(j) and LGEEPA's Article 87 and 87Bis., violating local communities material and knowledge rights.

National government response to these denuncias seems to have sided with civil society. In October 2000, after unsuccessful efforts to mediate the conflict, government denied a collection permit for the ICBG project, and in November 2001 the US government confirmed the project officially terminated. In the case of UNAMDiversa, the federal attorney recommended that the project be annulled until actors party to the contract respect existing legislation. Furthermore, it suggested that a broad-based public consultation be carried out in the design of regulatory norms and policies governing future bioprospecting access and benefit sharing arrangements.

Thus CS efforts appear to have been relatively successful in expressing public concerns around bioprospecting and in pressurising for more accountable legislative norms. Furthermore, the debate emanating from the CS actions effectively raised awareness with respect to legislative ambiguities around the issue of biological resource property rights, pointing out potential conflicts in terms of nationally- and locally- articulated environmental rights. In this way Mexico's debate around bioprospecting reflects discussions that are taking place in broader academic arenas, and the challenges that such initiatives have in practice.

Although the debate centred around the condemnation of these two projects, as it progressed another bioprospecting initiative negotiated between a community-based CS actor and a multinational pharmaceutical company was drawn into the debate. As will be seen, this example raises a number of questions related to how civil society at various levels interprets indigenous rights and the way in which bioprospecting inherently violates them. It is to this unique case that we now turn to. 


\section{Section 2: Bioprospecting in Oaxaca's Sierra Juárez}

In the early 1990s, in the state of Oaxaca, an organisation made up of four indigenous communities in the Sierra Juárez, the Unión de Comunidades Productoras Forestales Zapoteca-Chinantecas, or the UZACHI, negotiated a bioprospecting contract with the multinational pharmaceutical company, Sandoz (now Novartis). Most simply described, the contract involved the provision of microbiotic mushroom samples, collected from the UZACHI's forests, to Sandoz, in exchange for training and a fully-equipped laboratory for the collection and characterisation of the samples by the local communities. In addition to these infrastructure and capacity building components, the company agreed to pay monetary compensation for the samples themselves, as well as an agreed lump sum payment in the event that any commercial product derived from the samples proves profitable.

The local CS actors directly involved in negotiating and carrying out the project consider their bioprospecting experience a positive one that could contribute significantly to the communities' longer term sustainable development process. In contrast, neighbouring community representatives and CS organisations, as well as NGOs of national and international scope, condemn the initiative, and consider it similar to the two other projects described above.

Little attention was paid to the CS voice supporting the UZACHI-Sandoz project in the bioprospecting debate. In order to understand more fully the "local" perspective, it must be situated historically within a broader regional struggle for natural resources in the area. During the 1950s, Mexican forestry policy endorsed a system of forest concessions. The system was considered to be both environmentally detrimental and in violation of community-based land rights outlined in Mexico's Constitution. Coinciding with the 1970s rise in social movements in Mexico, community ejidos in the Sierra Juárez began to mobilise and articulate demands for control of their land's forests. In 1983, after much struggle and protest, the government chose not to renew the concession to the private sector and authorised communities to independently manage their forests.

In addition to the movement's success decentralising natural resource management and thus reinstating the rights of local citizens to manage and directly profit from their forests, a number of civil society institutions and relationships emerged from this struggle. Between 1985 and 1990 collaborative community efforts worked to centre technical forestry services around community objectives, while also building local capacity in the area of forestry management (SEMARNAP, Del. Oaxaca PROCYMAP 2000). It is out of one such initiative that the UZACHI was born.

The UZACHI acquired its legal status in 1989. It is an organisation with a membership made up of approximately 950 comuneros, representing four indigenous communities located in the Sierra Norte, in Oaxaca's Sierra Juárez. Comuneros, men whose livelihoods are dependent on natural resources (and thus benefit from participating in the communal decision-making process provided by the UZACHI), differ from other community members in that they are registered with the legal entity responsible for managing shared natural resources.

The UZACHI communities have a total land holding of 26,000 hectares, of which 88 per cent is forest cover (Ramírez Domínguez 1999). UZACHI communities have in common the objective of developing self-reliant natural resource management practices. Thus, primary among UZACHI's institutional strategy is capacity building among technicians and comuneros in the field of sustainable forest resource management. The UZACHI deals with forest or natural resource management 
issues, serving as a mechanism through which decisions in this area are made. It is also responsible for the development of project proposals. Proposals must be passed through the Delegate Assembly - a body made up of delegates nominated by comuneros participating in Community Assemblies, or asambleas.

The Oaxaca city-based NGO Estudios Rurales Ambientales, or ERA, has served as advisor to the UZACHI. Their relationship was born out of the period of struggle for community resource control in the Sierra, and even before ERA acquired legal status in 1984, it was involved in both natural resource management and capacity-building activities with communities that today constitute the UZACHI. According to both these organisations, it is ERA's respect for indigenous decision-making mechanisms, and a shared history of working together which has led to a strong and on-going partnership between ERA and the UZACHI. Most recently this has manifested itself in the area of bioprospecting.

\section{A bioprospecting affair: the collaboration of unlikely bedfellows}

The UZACHI became interested in bioprospecting when they discovered uninvited researchers collecting biological materials from their lands. With the raised awareness that their lands held something valuable, and an interest in benefiting from this apparent natural wealth, the UZACHI approached ERA for assistance. They felt that working in a collaborative arrangement with an actor knowledgeable in bioprospecting would "cut the chains of biopiracy" and allow the UZACHI to benefit directly from their land's biological wealth. It was through such an initiative that the UZACHI hoped to identify areas of highest potential for pharmaceutical production in their forests, and to create mechanisms to generate access to genetic resources to further their own bioprospecting capabilities. Between 1992 and 1995 ERA facilitated negotiations between the UZACHI and Sandoz, and after the community-based organisation terms and conditions were met, a bioprospecting contract was established between them. The project was initiated in 1995 and ended in 1998.

That this project was drawn into the debate and condemned alongside the ICBGMaya and UNAM-Diversa projects put under questions its claims to contribute towards positive community development. Interviews with UZACHI and ERA representatives, and CS actors critical of the initiative conveyed very differing interpretations of the issue.

The UZACHI perspective concurs with the CBD's understanding that bioprospecting is a means through which biologically diverse countries and localities can profit from their natural endowment(s). Bioprospecting is considered and treated as an opportunity for the UZACHI (and other small farmer and indigenous organisations) to exploit an emerging niche market of biological diversity. The wealth of biological diversity on their lands places them at an advantage. However, as the nature of the negotiations and the project suggest, technical capacity in terms of collecting, analysing and developing biological samples is necessary if such groups are to move beyond being raw materials providers.

Indeed, the nature of the contract reflects UZACHI's protectionist approach to their land and knowledge rights, and an active ownership of the project. For instance, the contract stipulated no-outsider access; Sandoz was not to access the site and it was the UZACHI (and ERA) who was to be responsible for selecting the collection sites, collecting the mushrooms, and categorising the samples. Access to indigenous knowledge was explicitly excluded from the contract. Effectively, in inviting the foreign company in and demanding accountability from them, the UZACHI filled an 
"accountability gap", creating a bilateral agreement between a community based organisation and a multinational corporate actor.

The UZACHI ownership of the project has had further effects. First, the negotiation process was seen as one that generated a lot of confidence among the UZACHI in terms of increased awareness and capacity to negotiate. Their decision to opt for a fixed-sum payment in the case that a compound of value be discovered, versus a percentage of royalties, demonstrates an appreciation that the company may not be honest in disclosing the total profit acquired from such a compound. They were also conscious of the time such developments often take. UZACHI's Ramírez Domínguez describes the "fixed-sum option" as a lottery ticket which may or may not have the winning number. It is not a gamble the UZACHI seem to be banking on.

Second, the direct involvement of the comuneros ensures sustainable use of resources, reinforcing the principle of "global subsidiarity": a presumption favouring local decision-making on the basis that it is more likely to respond to local needs and livelihood realities (Bellour and Newell 2001: 2). The CBO's holistic perception of the forest as a resource base and its understanding of the project as one element among others in a longer on-going process are confirmed by post-project initiatives that are making use of the technical and human infrastructure developed through the project. For instance, local biologists trained for the project are now employing advanced DNA analysis to research potential methods of increasing wild mushroom populations in their forests. If successful, the UZACHI plan to designate forest areas exclusively for the cultivation and sale of mushrooms, catering to an emerging niche market in this area. On-going research is also using advanced techniques to cultivate ornamental plants whose sale is meant to finance future maintenance of wilderness areas. Both research projects fall into the UZACHI's non-extractive forest development strategy.

In other words, bioprospecting in this case is treated as a means through which local community can exercise their rights to access and benefit from their environmental rights. The nature of the contract helps to ensure that knowledge and biodiversity access rights will be protected. Moreover, its negotiation generated a strong sense of local awareness, as well as of 'foreign' knowledge and practices. Furthermore, it created a strong sense of confidence among the UZACHI, both in its traditional decision-making mechanisms, and more generally, as an organisation. It could be argued that such intangible benefits might move beyond basic economic development needs, fostering a sense of cultural integrity, and a capacity to claim other rights in the future.

The ERA/UZACHI approach is not entirely in accordance with the CBD however. As a bilateral agreement negotiated between a communities based organisation, and a global corporate partner, it seems to have effectively side-stepped the actor traditionally governing natural resources - the state. This raises important questions about the project and its executors' accountability, particularly given the ambiguous nature of rights to access and benefit from biodiversity.

Irrespective of the role of the local indigenous voice in supporting the project, and its apparent positive influence on the capacity of the communities to preserve biodiversity in the area in the future, the project is condemned by neighbouring community representatives and CS organisations, as well as NGOs of national and international scope. These actors argue that the project was negotiated and carried out secretively, that the exchange negotiated was unfair and exploitative for the communities directly involved in the contract, as well as for neighbouring communities sharing similar biodiversity but not invited to participate in (and therefore 
benefit from) the exchange. Rather than a protection of rights through negotiation, they see the case as a violation of the environment and knowledge rights of indigenous communities.

\section{Section 3: Diverse understandings of rights and accountabilities}

The case of the UZACHI-Sandoz project illustrates the multifaceted nature of accountability. It also illustrates difficult challenges for how to build representative and responsible environmental governance in a contemporary multi-level, multiinstitutional system characterised by legislative ambiguities and contested interpretations of rights.

The UZACHI-Sandoz bioprospecting project has attempted to "cut the chains of biopiracy", and push for corporate accountability through a community-initiated bioprospecting endeavour. This has resulted in an institutional arrangement between "unlikely bedfellows" - the local community organisation and a multinational pharmaceutical company. That a number of combined elements made the deal possible cannot be emphasised enough. These include the capacity of the CBO to negotiate effectively with the multinational and to take ownership of the project. Also relevant is the ambiguous nature of regulatory frameworks in the field of bioprospecting and the contestation around property rights related to biodiversity.

To claim their perceived rights, and to make their claims for accountability on the part of the corporation, the citizens used their own form of indigenous organisation, in this case a comunero-run forum representing four indigenous communities, with the assistance of an NGO. The shared historical struggle of these communities, and the related concern for sustainable use of forest resources, legitimated a need for community control of the project. This, in conjunction with a pragmatic approach to conservation and development, led to the UZACHI's effective exploitation of the space left by the voice in global and national legislation regulating bioprospecting.

At the time of negotiation this combination of factors ensured a space for a bilateral agreement between the community-based organisation and the multinational corporation agreement, side-stepping the CBD's Article 15, and asserting local control over biodiversity resources exercised by the group of indigenous peoples. In this light the project supports the prevalence of Articles 8(j) and 87, 87Bis., in the CBD and Mexico's LGEEPA, respectively. And, in so doing, it appears to be a case from which other local and/ or indigenous groups also endowed with biological diversity could also learn.

On the other hand, other voices claiming to represent civil society disagree. For them the goods being negotiated are shared and non-commodifiable common goods; their privatisation threatens indigenous rights. Furthermore, the fact that they cannot be isolated as a resource - like a tree or a mushroom can, for instance - challenges a fair and equitable distribution of the benefits that might accrue from effective access to and exploitation of these 'biodiversity rights'.

The case clearly raises thorny issues of representation, legitimacy and accountability within civil society. Is it fair that one community based organisation benefit economically, or in terms of technical and human capital, from exercising their rights to what is effectively a common good? Or in other words, in such a case to whom are UZACHI and ERA accountable? As local civil society organisations, how accountable are they to their extra- and intra-community constituents or other project stakeholders? Indeed, who are those community members actively articulating their 
rights as members of the UZACHI? What are their interests? And how broad a base do they represent?

The case also challenges 'homogeneous' understandings of civil society and oversimplified perceptions of rights. It illustrates the differences within and amongst civil society actors, whose interests and perceptions of rights have themselves been shaped by differing social and historical circumstances, and may in fact be competing. In such cases, what are the potential conflicts that might emerge amongst civil society actors about whose rights are most legitimate? How might such conflicts build or draw upon already existing historical animosities? And, if this occurs, how might such conflicts be resolved?

These are difficult questions which cannot be ignored in debates about how citizens participate in claiming their rights, and in holding corporate and state actors accountable. Ultimately, those who promote the new role of civil society as actors in upholding rights, and as watchdogs in holding corporate and state actors accountable, must also examine and address issues of representation and diversity within civil society itself.

\section{References}

Newell, P. and Bellour,S. 2001, Mapping Accountability: Origins, Contexts and Implications for Development, Draft Paper for DRC Brighton: IDS CBD. 1992. Convention on Biological Diversity: Text and Annexes. Convention on Biological Diversity Interim Secretariat, Geneva Executive Centre.

McAfee, K. 1999. Selling Nature to Save it? Biodiversity and green developmentalism. Environment and Planning D: Society and Space 17:133154.

Pimbert, M. 1997. Issues Emerging in Implementing the Convention on Biological Diversity. Journal of International Development 9:415-425.

Ramirez Dominguez, R. 1999. "El Manejo Comunitario de los Recursos Forestales, una Opcion para las Comunidades Campesinas." Retos y oportunidades para el approvechamiento sostenible de especies no maderables en Mexico y Centroamerica, Oaxaca, Mexico, 1999.SEMARNAP, D. O., and PROCYMAF. 2000. Conservacion y manejo comunitario de los recursos forestales en Oaxaca. Oaxaca, Oaxaca: SEMARNAP. Shiva, V. 1997. Biopiracy: the plunder of nature and knowledge. Boston: South End Press.

\footnotetext{
${ }^{1}$ I am indebted to Jutta Blauert, John Gaventa, Alex Shankland, Peter Newell and Joanna Howard for their comments and on-going support. I would also like to thank CECCAM, ERA, GEA, RAFI and the UZACHI for their participation in this research endeavour, and the DRC on Participation, Citizenship and Accountability for inspiration, and for making the fieldwork upon which this research is based possible.
} 